\title{
Monitoring chloride-induced corrosion of carbon steel tendons in concrete using a multi-electrode system
}

\author{
A. Brenna, L. Lazzari, M. Ormellese* \\ Politecnico di Milano, Dipartimento di Chimica, Materiali e Ingegneria Chimica “Giulio Natta”, Via Mancinelli 7, 20131 Milano, Italy
}

\section{H I G H L I G H T S}

- A novel multi-reference-electrode (MuRE) was proposed and studied.

- Nickel and stainless steel were the more stable metals for the reference electrode.

- The MuRE is able to detect and locate the chloride-induced corrosion.

- The proper length of each wire is influenced by the cover and the resistivity.

- The maximum allowable length/cover ratio to detect the localized corrosion is 50.

\section{A R T I C L E I N F O}

\section{Article history:}

Received 17 February 2015

Received in revised form 30 July 2015

Accepted 9 August 2015

\section{Keywords:}

Concrete

Corrosion

Durability

Chloride

Monitoring

Reference electrode

\begin{abstract}
A B S T R A C T
To monitor real-time the occurrence of localized corrosion in reinforced concrete structures a novel multi-reference electrode is proposed, consisting of a series of metallic wires placed head-to-tail able to measure the corrosion potential of a carbon steel tendon or a rebar network. Available embeddable or portable reference electrodes give the local potential of the rebar; with the new system, a single potential reading can give the corrosion condition of a wide area. Copper, nickel and stainless steel were tested as candidate metallic materials: laboratory tests allow verifying their stability in alkaline condition. The ability to detect and locale corrosion was demonstrated on mortar and grout specimens, cast to simulate chloride-induced corrosion on post-tensioned tendons.
\end{abstract}

(c) 2015 Elsevier Ltd. All rights reserved.

\section{Introduction}

Carbon steel reinforcements and tendons are in passive condition in pristine concrete, due to the high alkalinity of the water pore solution: a thin layer of iron oxides covers the steel surface, reducing corrosion rate to practically negligible values, lower than $1 \mu \mathrm{m} / \mathrm{y}$ [1]. Concrete carbonation and chlorides penetration are the two main causes of corrosion initiation. In the first case, carbon dioxide penetrating into concrete from the atmosphere reacts with the alkaline compounds of the pore solution, promoting a reduction of $\mathrm{pH}$ to almost neutrality: carbon steel passivity is destroyed and corrosion propagates on all rebar surface in contact with the neutralized concrete, provided the presence of water and oxygen.

\footnotetext{
* Corresponding author.

E-mail addresses: andrea.brenna@polimi.it (A. Brenna), luciano.lazzari@polimi.it (L. Lazzari), marco.ormellese@polimi.it (M. Ormellese).
}

Corrosion rate is in the range of tens of $\mu \mathrm{m} / \mathrm{y}$, up to $100 \mu \mathrm{m} / \mathrm{y}$ [1]. Chloride-induced corrosion initiates once a critical chloride threshold is reached at the rebar level: the passivity is locally destroyed and corrosion propagates at a very high corrosion rate, typically in the range of $1 \mathrm{~mm} / \mathrm{y}$ [1]. In the presence of high strength steels, such as tendons for pre-stressed or posttensioned structures, brittle fracture due to hydrogen embrittlement may occur, promoting possible catastrophic collapse of the structure. In fact, once a localized corrosion attack occurs, acid condition sets up at the pit tip, producing hydrogen atoms and promoting hydrogen embrittlement on susceptible steels [1-3].

Prevention of corrosion begins in the design phase, accordingly materials and prevention techniques are selected, concrete is properly cast and cured. International standard EN 206 [4] and Eurocode 2 [5] suggest $\mathrm{W} / \mathrm{C}$ ratio, concrete cover, cement type and curing time to achieve the designed service life according to the environmental aggressiveness. As regard pre-stressed or 
post-tensioned concrete structures, from 90's more attention was paid in establishing technical specifications, selecting materials, for instance the use of drawing steel instead of quenched and tempered steels, defining design strategies to avoid the risk of brittle fracture [2-5].

In very severe working condition, if a very long service life is required, additional protection techniques may be used, such as corrosion resistant bars, concrete coating, corrosion inhibitors, cathodic protection or prevention [6-8]. Prevention of corrosion continues throughout the entire service life of the structure with scheduled inspection, maintenance and above all monitoring [2-5].

The latter is of paramount importance for the safety of a reinforced concrete structure: visual inspection, chloride content determination, carbonation measurements, acoustic emission, ultrasonic and magnetic methods, resistivity measurements, are all useful to define the concrete quality, its pollution and presence of cracks [9-15].

The measurement of the free corrosion potential is essential to monitor the corrosion process of reinforcing steel in concrete $[7,16-18]$. Rebar potential is measured with respect a portable or embedded reference electrode by means of a high impedance voltmeter $(>10 \mathrm{M} \Omega)$. The most used portable electrode is the copper/copper sulphate reference electrode (CSE), consisting in a copper rod immersed in a saturated copper sulphate solution. It is typically used in potential mapping, the only recognized and standardizes non-destructive technique for a direct assessment of reinforcement corrosion [7,18-19]. American standard ASTM C876 [18] describes the procedure to perform a potential mapping and it gives a guideline to interpret the readings. The measured potential corresponds to the equipotential surface intercepted by the local reference electrode, place on the external surface of the concrete, or embedded into it. The standard states: the probability of corrosion is very low if rebar potential is more noble than $-200 \mathrm{mV}$ CSE, whereas the probability of corrosion is very high if the rebar free corrosion potential is more negative than $-350 \mathrm{mV}$ CSE [18]. The experience with potential mapping of the last 20 years has been included in a RILEM recommendation [19], confirming the reported thresholds.

Various solid reference sensors embeddable in concrete have been developed [20-28]. They are very useful for long-term corrosion monitoring of concrete structures in freely corroding condition as well as in the presence of cathodic protection [20-21]. Moreover, the use of remote monitoring requires reference electrode with an extended stability [22-23]. The embedded electrodes must obey some conditions: inert to chemical and thermal changes in concrete, not polarizable, long-term stability and cost effective. The long-term stability of reference electrodes is a critical issue $[16,20,24]$. Among embedded reference electrode the most studied are manganese dioxide $\left(\mathrm{MnO}_{2}\right)$, also used as $\mathrm{pH}$ and humidity sensors, and titanium rods activated with mixed-metal oxide [21,22,25-28]. $\mathrm{MnO}_{2}$ sensor seems to be the most stable and reliable potential sensor electrode for concrete structures. However, the long-term stability of the embedded $\mathrm{MnO}_{2}$ sensor in concrete is essential for online monitoring applications [21,22].

Even if local reference electrodes are very stable and reliable, they measure a local value corresponding to the intercepted equipotential surface. Then, to monitor the corrosion condition of a wide reinforced concrete structures, or to control the initiation of corrosion on long carbon steel tendons, several local reference electrodes should be installed, or expensive potential mapping should be performed [29].

To cope this problem, a new wire-type reference electrode was proposed: the wire can be placed along the rebar network or along the tendon, and a single potential reading can give the corrosion condition of a wide surface area. Firstly, laboratory tests were performed to understand the meaning and the reliability of the potential reading performed by a wire reference electrode; results are reported in [30]. In this paper, a new conceived reference electrode for pitting corrosion monitoring is presented; it consists of a series of Multiple wire-type Reference Electrodes (named MuRE) placed head-to-tail to cover the whole rebar network, or the whole length of a carbon steel tendon. Each reference electrode has a proper active length in relation to the geometry of the structure and the concrete or grout resistivity. Aim of the paper is to determine the stability of the metallic materials selected as reference electrode in alkaline condition and to define the proper length of a single reference electrode wire in order to realize a MuRE system suitable for detecting the occurrence of chloride-induced corrosion on long carbon steel tendons, especially those encased in polymeric ducts.

\section{Experimental}

Four metallic wires, $0.8 \mathrm{~mm}$ in diameter, were tested as reference electrodes: copper, nickel, austenitic stainless steel UNS S31600 and oxidized austenitic stainless steel. Chemical composition of the metal wires is reported in Table 1. Oxidation of stainless steel was achieved in a furnace at $800^{\circ} \mathrm{C}$ for $20 \mathrm{~min}$.

Stability in alkaline environment and ability to detect chlorideinduced corrosion were tested.

\subsection{Stability in alkaline environment}

Stability of the four selected metallic materials was tested in two slabs $(200 \times 100 \times 50 \mathrm{~mm})$, cast with a commercial grout using Ordinary Portland Cement CEM II $42.5 \mathrm{R}$ and W/C ratio 0.3, to reduce the risk of bleeding. A commercial super-plasticizer was added in dosage $4 \%$ by cement weight to produce a flowable, pumpable, non-shrinkable, non-segregating grout. The superplasticizer was a chloride-free powder admixture, for specific use in the production of grouts for post-tensioned cables in prestressed concrete structures.

For each metal, a $300 \mathrm{~mm}$ long wire was placed in the specimen. Metal potential was measured with an external CSE reference electrode placed on the top of the specimen by means of a wet sponge (Fig. 1). Potential was detected for the first 5 days with a data logger (frequency $0.1 \mathrm{~Hz}$ ), then with manual periodical measurement for next three months.

\subsection{Chloride-induced corrosion detection}

Carbon steel tendons encased in grouted plastic ducts were simulated with a polymeric cylindrical cell, $50 \mathrm{~mm}$ in diameter and $2500 \mathrm{~mm}$ in length, containing a carbon steel rebar, $10 \mathrm{~mm}$ in diameter. Cover, $D$, was $20 \mathrm{~mm}$ (Fig. 2).

For each metallic material, three multi-reference-electrodes (MuREs) were prepared with different $L / D$ ratio $(5,15$ and 40 respectively), where $L$ is the length of one active wire and $D$ is the grout cover. Being the polymeric cell $2500 \mathrm{~mm}$ long and the cover $20 \mathrm{~mm}$ thick, a single wire of the three multi reference electrodes is $100 \mathrm{~mm}, 300 \mathrm{~mm}$ and $800 \mathrm{~mm}$ long, respectively. Accordingly, 26, 9 and 3 electrodes has been installed for the MuRE with $L / D$ ratio 5, 15 and 40 , respectively. A linear continuous

Table 1

Chemical composition of selected metallic materials.

\begin{tabular}{lllllllll}
\hline & $\mathrm{Si}$ & $\mathrm{Ti}$ & $\mathrm{Cr}$ & $\mathrm{Mn}$ & $\mathrm{Fe}$ & $\mathrm{Ni}$ & $\mathrm{Cu}$ & $\mathrm{Mo}$ \\
\hline Copper (Cu) & - & - & - & - & - & - & 100.00 & - \\
Nickel (Ni) & 1.17 & 3.76 & - & 0.61 & - & 94.95 & - & - \\
AISI 316 (SS) & 1.13 & - & 19.05 & 1.72 & 62.22 & 12.20 & - & 3.67
\end{tabular}




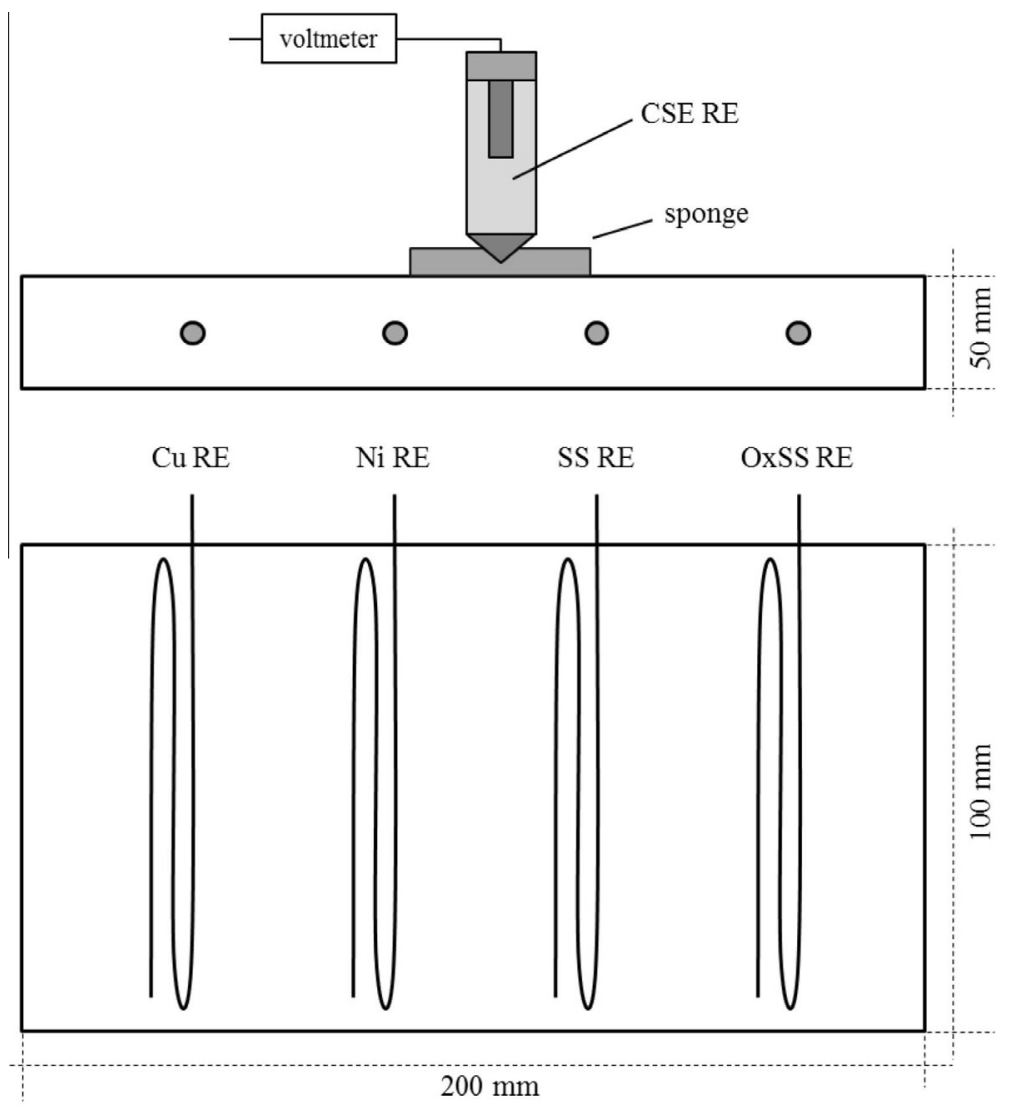

Fig. 1. Grout slab for stability tests.

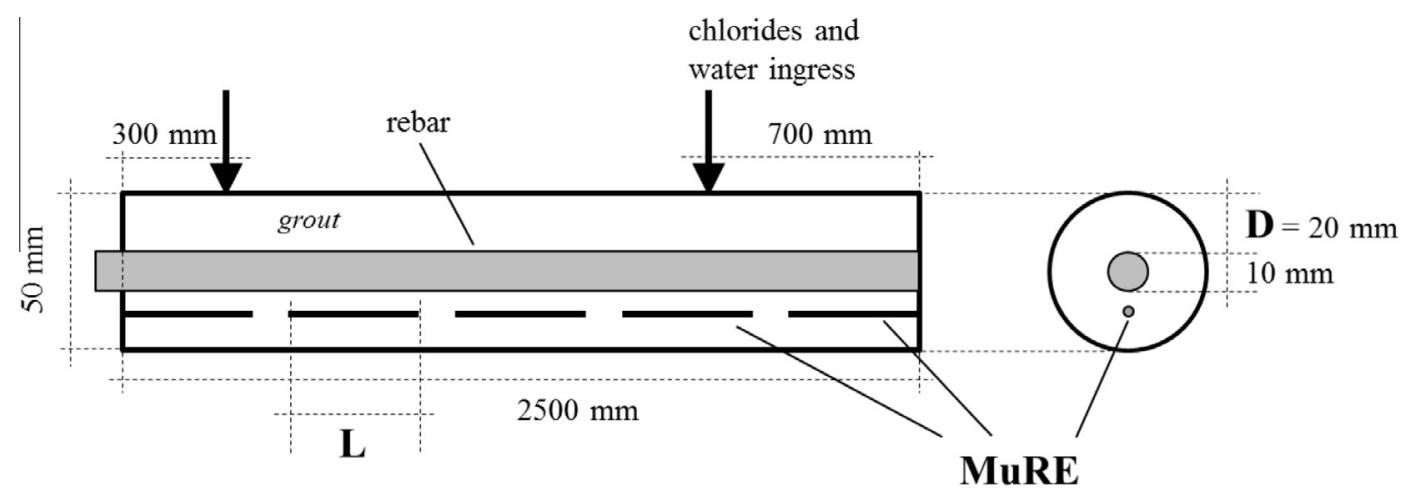

Fig. 2. Grout sample simulating localized corrosion occurrence on post-tensioned tendons encased in grouted plastic ducts.

reference electrode (LCRE) $2.5 \mathrm{~m}$ long was also embedded into the cell for comparison purposes.

Polymeric cells were filled with the same commercial grout described in paragraph 2.1; curing time was 3 days.

Two experimental conditions were considered: the influence of water variation into the grout and the chloride-induced corrosion, due both to possible damages in the plastic ducts. After curing, two $5 \mathrm{~mm}$ holes were drilled at $700 \mathrm{~mm}$ and at $300 \mathrm{~mm}$ from the two ends of the polymeric cylinder (distance between the two holes was $1.5 \mathrm{~m}$ ). Fresh water was daily added for 7 days in the first hole. In the specimens exposed to chloride-induced corrosion tests, a $3.5 \% \mathrm{NaCl}$ solution was continuously added for 3 weeks in the same hole. In proximity of the hole, the rebar potential was measured by the wire n. 20 of the MuRE with $L / D$ ratio 5, by the wire $n .7$ of the MuRE with $L / D$ ratio 15 and by the wire $n$. 3 of the MuRE with $L / D$ ratio 40 . The second hole was used to verify carbon steel passivity at $1.5 \mathrm{~m}$ far away from the chloride ingress.

Summarizing, for each metallic material four cylindrical specimens were cast, two for water variation tests and two for chlorides tests. For each experimental condition one cylindrical cell was cast with two MuREs ( $L / D$ ratio 15 and 40, respectively), and the other with the MuRE with $L / D$ ratio 5 and with the LCRE. Both the MuREs and the LCRE were placed along the carbon steel rebar (Fig. 2). A total of 16 grouted cylindrical specimens with an internal carbon 
Table 2

Test condition and samples.

\begin{tabular}{|c|c|c|c|}
\hline Reference electrodes & Test condition & & $\operatorname{MuRE}(L / D)-$ LCRE \\
\hline Copper (Cu) & $\begin{array}{l}\text { Humidity test } \\
\text { Chlorides test }\end{array}$ & $\begin{array}{l}\text { A1 } \\
\text { A2 } \\
\text { B1 } \\
\text { B2 }\end{array}$ & $\begin{array}{l}\text { MuRE (5) - LCRE } \\
\text { MuRE (15) - MuRE (40) } \\
\text { MuRE (5) - LCRE } \\
\text { MuRE (15) - MuRE (40) }\end{array}$ \\
\hline Nickel (Ni) & $\begin{array}{l}\text { Humidity test } \\
\text { Chlorides test }\end{array}$ & $\begin{array}{l}\text { A5 } \\
\text { A6 } \\
\text { B5 } \\
\text { B6 }\end{array}$ & $\begin{array}{l}\operatorname{MuRE}(5)-\text { LCRE } \\
\text { MuRE (15) - MuRE (40) } \\
\text { MuRE (5) - LCRE } \\
\text { MuRE (15) - MuRE (40) }\end{array}$ \\
\hline Stainless Steel (SS) & $\begin{array}{l}\text { Humidity test } \\
\text { Chlorides test }\end{array}$ & $\begin{array}{l}\text { A3 } \\
\text { A4 } \\
\text { B3 } \\
\text { B4 }\end{array}$ & $\begin{array}{l}\text { MuRE (5) - LCRE } \\
\text { MuRE (15) - MuRE (40) } \\
\text { MuRE (5) - LCRE } \\
\text { MuRE (15) - MuRE (40) }\end{array}$ \\
\hline $\begin{array}{l}\text { Oxidised Stainless Steel } \\
\quad(\mathrm{ox}-\mathrm{SS})\end{array}$ & $\begin{array}{l}\text { Humidity test } \\
\text { Chlorides test }\end{array}$ & $\begin{array}{l}\text { A7 } \\
\text { A8 } \\
\text { B7 } \\
\text { B8 }\end{array}$ & $\begin{array}{l}\operatorname{MuRE}(5)-\operatorname{LCRE} \\
\text { MuRE (15) - MuRE (40) } \\
\text { MuRE (5) - LCRE } \\
\text { MuRE (15) - MuRE (40) }\end{array}$ \\
\hline
\end{tabular}

steel rebar were cast to simulate real tendons encased in grouted plastic ducts. Table 2 resumes test conditions and specimens.

The following measurements were performed:

- Carbon steel rebar potential with respect to the embedded reference electrodes,

- Potential of the embedded reference electrodes with respect to an external CSE placed in the two holes,

- Carbon steel rebar potential with respect to an external CSE placed in the two holes.

Potentials were daily measured for the first two weeks after casting, then three measurements in a week were carried out.

\section{Results}

\subsection{Stability in alkaline environment}

Fig. 3 shows the potential measurements of the four metallic materials embedded in grout specimens, performed with an external CSE, in the first week after casting and for three following months. In the first two days after casting, a potential variation was observed, irrespective to the metal tested (Fig. 3a). A characteristic peak was observed $20 \mathrm{~h}$ after casting, related to the grout setting time. Then potentials grew up reaching a stable value for each metal wire (Fig. 3b): $-0.1 \mathrm{~V}$ CSE for nickel; $-0.2 \mathrm{~V}$ CSE for copper and oxidized stainless steel; AISI 316 stabilized at $-0.2 \mathrm{~V}$ CSE, even if in the last month potential increased towards $-0.1 \mathrm{~V}$ CSE. Nickel showed the more stable behavior.

\subsection{Potential monitoring}

Measured rebar potential profiles are reported in Fig. 4. For clarity, only profiles obtained with the MuRE with $L / D$ ratio 5 are reported. Similar trend has been obtained with the MuREs with higher $L / D$ ratios. Table 3 summarises potential ranges obtained in all tested conditions.

In pristine concrete (i.e. no water nor chlorides addition), carbon steel potential was in the range of $+20 /+100 \mathrm{mV}$ with respect to all the Cu-MuREs, in the range of $+10 /+20 \mathrm{mV}$ with respect to the SS-MuREs, in the range of $-60 /-90 \mathrm{mV}$ with respect to the $\mathrm{Ni}-\mathrm{MuREs}$ and in the range of $-50 /-80 \mathrm{mV}$ with respect to the OxSS-MuREs (Table 3). The measured values indicate that carbon steel rebar was in passive conditions. Passivity was confirmed by potential readings performed with an external CSE placed in the hole drilled at $700 \mathrm{~mm}$ from one end of the cell: values in the range of $-100 /-200 \mathrm{mV}$ CSE were measured.

After one week of water addition, a uniform positive potential shift, in the range of $20-50 \mathrm{mV}$, was observed (Fig. 4 and Table 3). Since the reference electrodes of the MuRE close to the area where water was added do not detect any significant potential variation, it can be stated that the MuREs are not influenced by water content variation.

After three weeks of continuous addition of a $3.5 \% \mathrm{NaCl}$ solution, a local decrease of rebar potential was detected by wire of the MuRE in the area close to the pit (Fig. 4). A $200-300 \mathrm{mV}$ decrease in rebar free corrosion potential, measured with an external CSE reference electrode, confirmed the initiation of a localized corrosion attack: at the pit site carbon steel potential decreased from $-100 \mathrm{mV}$ CSE to $-400 \mathrm{mV}$ CSE; at the hole $1.5 \mathrm{~m}$ far away from the salty water addition, potential was stable close to $-100 \mathrm{mV}$ CSE, confirming rebar passive condition.

The reference electrode wires of the MuRE located in the area close to the anodic site showed a similar potential variation after chloride addition. As reported in Fig. 4, in the case of Cu-MuRE with $L / D$ ratio 5 , rebar potential profile ranges from $+50 /+120 \mathrm{mV}$ in passive conditions $(0-120 \mathrm{~cm})$ to $-150 \mathrm{mV}$ at the pit site. In the case of Ni-MuRE, rebar potential ranged from $-50 /-70 \mathrm{mV}$ for passive steel $(0-100 \mathrm{~cm})$ to $-250 \mathrm{mV}$ near the pit. Similar profiles were measured in the case of SS-MuRE and OxSS-MuRE.

Carbon steel potential variation measured with the MuREs with higher $L / D$ ratio are summarized in Table 3 . Rebar potential measured with respect to the Cu-MuREs decreased from +60 / $+120 \mathrm{mV}$ in passive condition, to $-120 \mathrm{mV}$ in the case of $L / D$ ratio
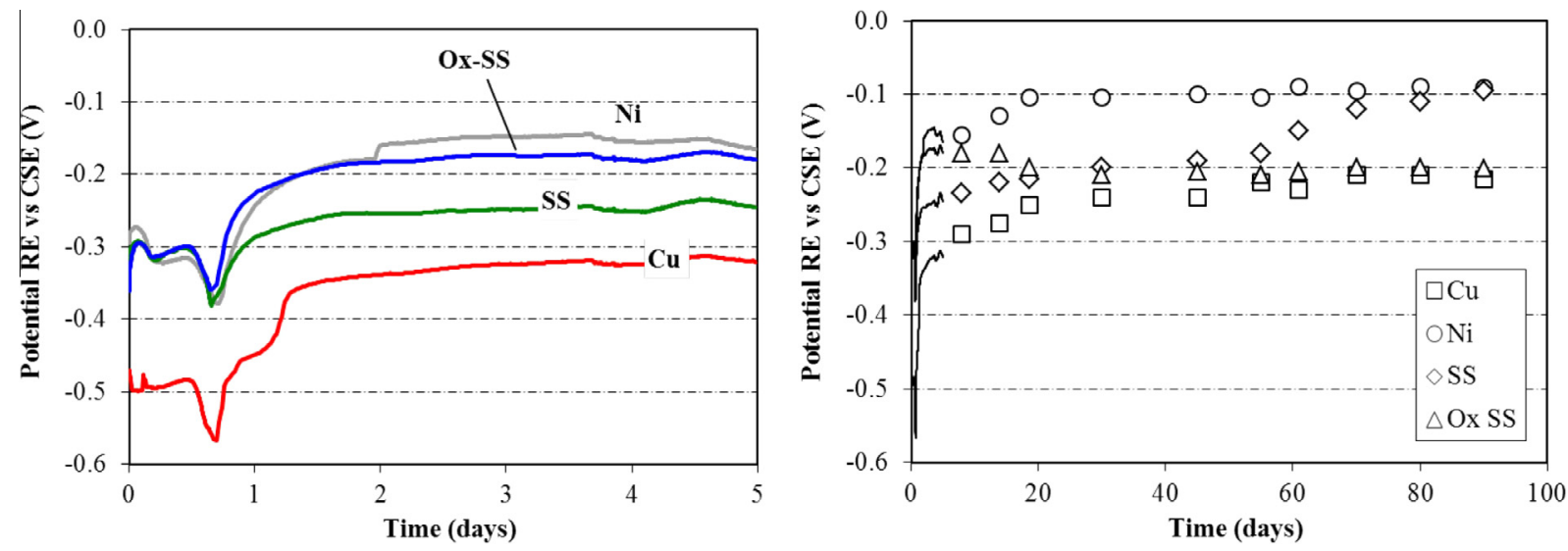

Fig. 3. Potential trend of the four metallic wires embedded in grout slabs, measured with respect an external CSE reference electrode. 

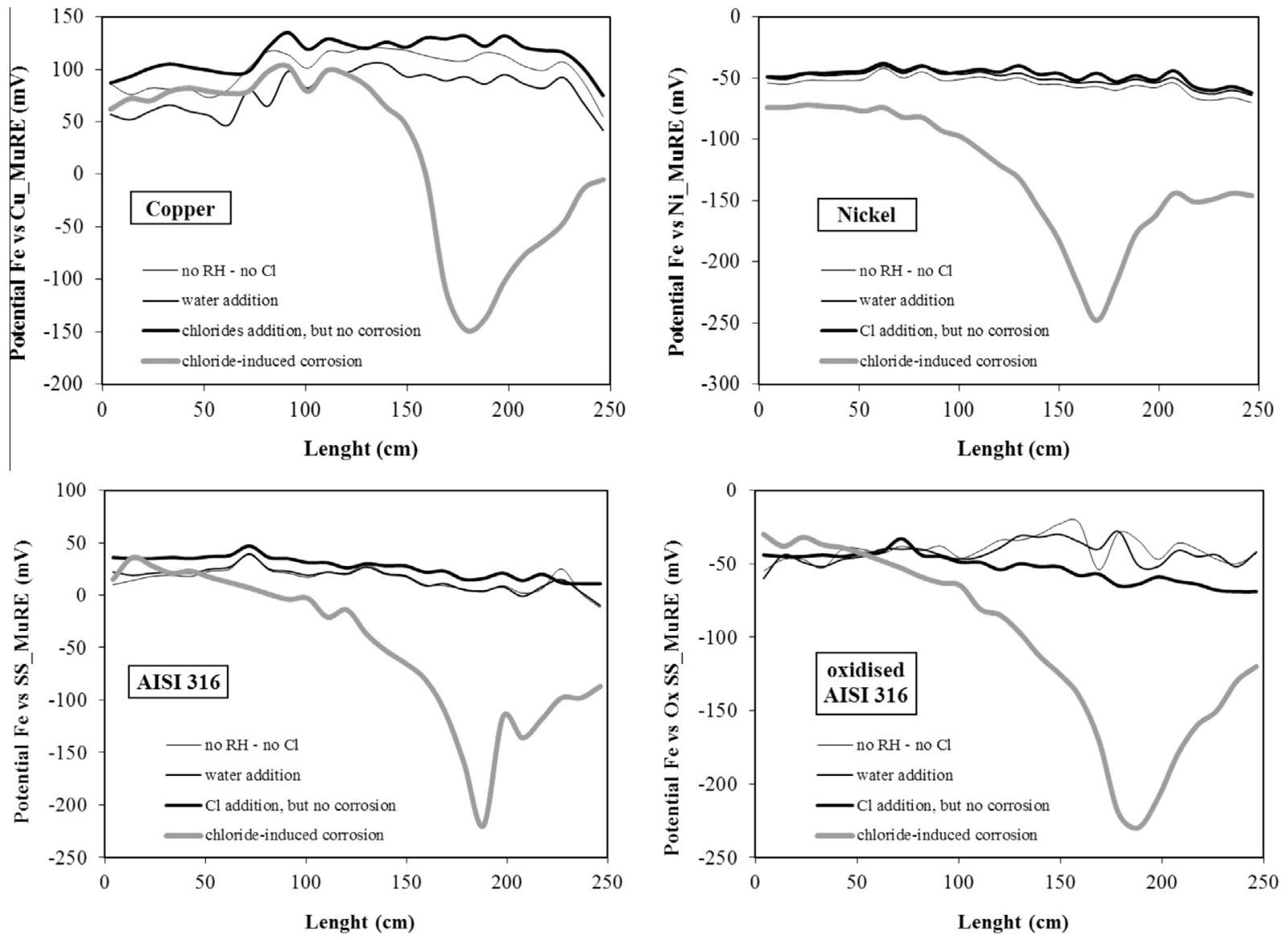

Fig. 4. Rebar potential profile measured with respect to the MuRE with $L / D$ ratio 5.

Table 3

Rebar potential range ( $\mathrm{mV}$ ) with respect to MuRE and to LCRE.

\begin{tabular}{|c|c|c|c|c|c|c|}
\hline \multicolumn{3}{|c|}{ Reference electrode } & $\begin{array}{l}\text { No water and chlorides addition }{ }^{\mathrm{a}} \\
+30 /+100\end{array}$ & $\begin{array}{l}\text { Presence of water }^{\mathrm{a}} \\
+40 /+110\end{array}$ & \multicolumn{2}{|l|}{ Chlorides induced corrosion } \\
\hline $\mathrm{Cu}$ & LCRE & $\begin{array}{l}L / D=5 \\
L / D=15 \\
L / D=40\end{array}$ & $\begin{array}{l}+30 /+100 \\
+20 /+70 \\
+60 /+100 \\
+50 /+100\end{array}$ & $\begin{array}{l}+40 /+110 \\
+20 /+70 \\
+70+80 \\
+80 /+100\end{array}$ & $\begin{array}{l}+50 /+120 \\
+60 /+100 \\
+60 /+120 \\
+80 /+100\end{array}$ & $\begin{array}{l}-150 \\
-120 \\
-110 \\
+10\end{array}$ \\
\hline $\mathrm{Ni}$ & $\begin{array}{l}\text { MuRE } \\
\text { LCRE }\end{array}$ & $\begin{array}{l}L / D=5 \\
L / D=15 \\
L / D=40\end{array}$ & $\begin{array}{l}-60 /-90 \\
-70 /-90 \\
-70 /-80 \\
-70 /-80\end{array}$ & $\begin{array}{l}-30 /-40 \\
-40 /-50 \\
-40 /-50 \\
-50 /-60\end{array}$ & $\begin{array}{l}-40 /-60 \\
-50 /-80 \\
-60 /-80 \\
-50 /-60\end{array}$ & $\begin{array}{l}-250 \\
-230 \\
-210 \\
-90\end{array}$ \\
\hline SS & $\begin{array}{l}\text { MuRE } \\
\text { LCRE }\end{array}$ & $\begin{array}{l}L / D=5 \\
L / D=15 \\
L / D=40\end{array}$ & $\begin{array}{l}+10 /+50 \\
+10 /+30 \\
+10 /+20 \\
+10 /+20\end{array}$ & $\begin{array}{l}+20 /+40 \\
+20 /+40 \\
+20 /+40 \\
+20 /+40\end{array}$ & $\begin{array}{l}+30 /+40 \\
+30 /+40 \\
+30 /+40 \\
+30 /+40\end{array}$ & $\begin{array}{l}-200 \\
-145 \\
-100 \\
-30\end{array}$ \\
\hline ox-SS & $\begin{array}{l}\text { MuRE } \\
\text { LCRE }\end{array}$ & $\begin{array}{l}L / D=5 \\
L / D=15 \\
L / D=40\end{array}$ & $\begin{array}{l}-50 /-80 \\
-60 /-70 \\
-60 /-70 \\
-50 /-60\end{array}$ & $\begin{array}{l}-60 /-80 \\
-60 /-80 \\
-60 /-80 \\
-30 /-40\end{array}$ & $\begin{array}{l}-70 /-80 \\
-60 /-80 \\
-60 /-80 \\
-50\end{array}$ & $\begin{array}{l}-210 \\
-230 \\
-210 \\
-90\end{array}$ \\
\hline
\end{tabular}

a Potentials measured with respect to MuRE.

b Potentials measured with respect to MuRE near the pit (the 20th, the 7th and the 3rd electrode, respectively).

15 and to $-100 \mathrm{mV}$ in the case of $L / D$ ratio 40 , when localized corrosion occurred. Rebar potential measured with respect to the SSMuREs ranged from $+30 /+40 \mathrm{mV}$ in passive condition, to $-200 \mathrm{mV}$ in the case of $L / D$ ratio 5 , to $-150 \mathrm{mV}$ in the case of $L / D$ ratio 15 and to $-100 \mathrm{mV}$ in the case of $L / D$ ratio 40 . In the presence of Ni-MuRE rebar potential decreased from $-50 \mathrm{mV}$ in passive condition, to $-250 \mathrm{mV}$ in the case of $L / D$ ratio 5 , to $-230 \mathrm{mV}$ in the case of $L / D$ ratio 15 and to $-210 \mathrm{mV}$ in the case of $L / D$ ratio 40 . A strange behavior was observed in the case of OxSS-MuRE: the higher potential shift was measured in the presence of the MuRE with $L / D$ ratio 15 .

Rebar potential was measured with respect the LCRE: after chloride addition, a limited potential reduction was observed, never exceeding $100 \mathrm{mV}$. 

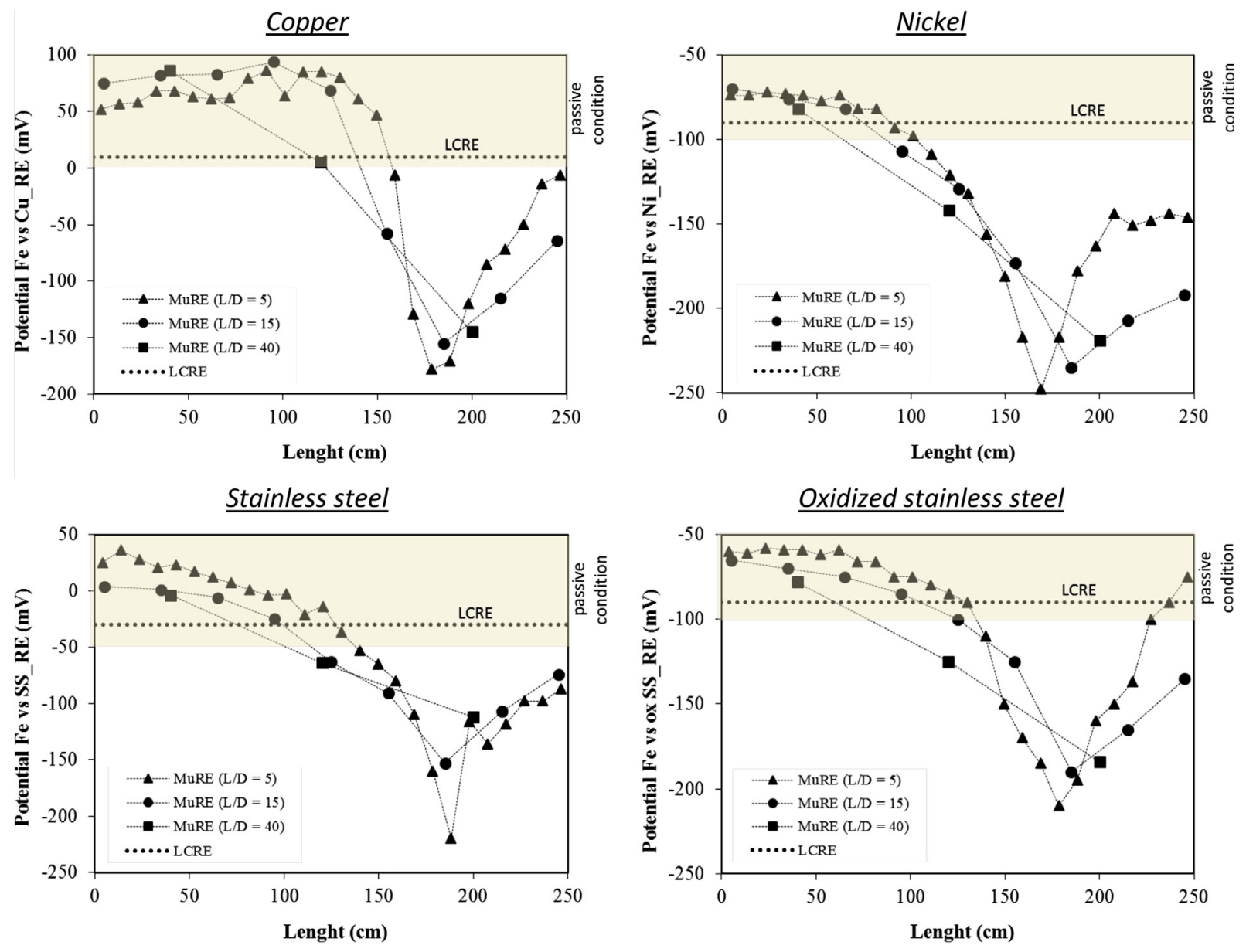

Fig. 5. Potential profiles measured with respect to the LCRE and to the MuREs in the presence of a localized corrosion attack.

\section{Discussion}

The experimental results allow discussing the capability of the MuREs to detect corrosion initiation and their ability to locate the anodic area. A comparison between LCRE and MuRE has been performed. Finally, the proper length of each metallic wire of the MuRE was calculated according to the mechanism by which the MuREs work.

\subsection{Chloride-induced corrosion detection}

Fig. 5 shows potential profiles measured with the MuREs and with the LCRE. Passive potential interval, in which the probability of corrosion is very low ( $<10 \%$, according to ASTM C876 [18]), is highlighted.

All the tested MuREs are able to detect the occurrence of localized corrosion. In fact, after three weeks of chlorides addition, the wires of the reference electrode of the MuREs close to the pit measured a reduction of free corrosion potential of about $200 \mathrm{mV}$ (Fig. 5 and Table 3): according to ASTM C876 [18] this potential shift indicates a probability of corrosion higher than $90 \%$. Pit initiation was confirmed by potential measured with the external CSE. The reference electrodes of the MuREs far away from the pit measured no potential variation, confirming the passive condition of the rebar far away from the site of chloride addition.

The MuREs are able both to detect the initiation of corrosion, thought the potential reduction, and to locate the anodic site, where corrosion initiated: in fact only the wires close to the anodic site showed the potential shift.

Comparing the potential profiles, the higher the $L / D$ ratio, i.e. the higher the length $L$ of the linear reference electrodes, the lower the potential shift when the chlorides induced corrosion occurred (Table 3). Practically, the MuRE with the lower $L / D$ ratio, i.e. the lower length $L$ of the active portion of the reference electrode, better localizes the corrosion attack. The MuREs with the $L / D$ ratio 40 (i.e. wire length $L 800 \mathrm{~mm}$ ) detect the corrosion initiation, but they do not exactly localize it, since the potential they measure is related to a portion of the rebar $800 \mathrm{~mm}$ long. Consequently, the MuRE with the lower $L / D$ ratio better localizes corrosion, since each wire is monitoring a small portion of rebar.

Summarizing, to monitor and to localize the corrosion attack on a tendon, a MuRE with an adequate $L / D$ ratio should be installed. The definition of the proper $L / D$ ratio is then mandatory.

\subsection{Comparison LCRE and MuRE}

Fig. 5 and Table 3 show rebar potential measurements performed with a linear-continuous reference-electrode (LCRE). Accordingly, in all the tested conditions after chloride addition, the four LCREs detect a maximum potential reduction from passive condition of about $100 \mathrm{mV}$, in the case of Cu-LCRE. This reduction is not sufficient to state with confidence that corrosion occurred on the rebar [18]. Then LCRE is not effective in clearly detecting the initiation of localized corrosion. In any case a single LCRE do not even allow to locate exactly where corrosion started, since the 
Table 4

Potential of the MuRE systems ( $\mathrm{mV}$ ) with respect to an external SCE.

\begin{tabular}{|c|c|c|c|c|c|}
\hline \multirow[t]{2}{*}{ Reference electrode } & \multicolumn{3}{|l|}{ MuRE } & \multirow[t]{2}{*}{ LCRE } & \multirow[t]{2}{*}{ Corrosion rebar condition } \\
\hline & $L / D=5$ & $L / D=15$ & $L / D=40$ & & \\
\hline $\mathrm{Cu}$ & $\begin{array}{l}-220 \\
-270 \\
-200\end{array}$ & $\begin{array}{l}-210 \\
-240 \\
-200\end{array}$ & $\begin{array}{l}-240 \\
-250 \\
-220\end{array}$ & $\begin{array}{l}-200 \\
-270 \\
-180\end{array}$ & $\begin{array}{l}\text { No localized corrosion } \\
\text { Presence of localized corrosion SCE near the pit } \\
\text { Presence of localized corrosion SCE } 1.5 \mathrm{~m} \text { far from the pit }\end{array}$ \\
\hline $\mathrm{Ni}$ & $\begin{array}{l}-130 \\
-270 \\
-120\end{array}$ & $\begin{array}{l}-140 \\
-290 \\
-130\end{array}$ & $\begin{array}{l}-140 \\
-300 \\
-130\end{array}$ & $\begin{array}{l}-120 \\
-170 \\
-60\end{array}$ & $\begin{array}{l}\text { Presence of localized corrosion SCE near the pit } \\
\text { Presence of localized corrosion SCE } 1.5 \mathrm{~m} \text { far from the pit }\end{array}$ \\
\hline SS & $\begin{array}{l}-145 \\
-270 \\
-140\end{array}$ & $\begin{array}{l}-150 \\
-250 \\
-150\end{array}$ & $\begin{array}{l}-160 \\
-280 \\
-150\end{array}$ & $\begin{array}{l}-150 \\
-240 \\
-110\end{array}$ & $\begin{array}{l}\text { No localized corrosion } \\
\text { Presence of localized corrosion SCE near the pit } \\
\text { Presence of localized corrosion SCE } 1.5 \mathrm{~m} \text { far from the pit }\end{array}$ \\
\hline $\mathrm{ox}-\mathrm{SS}$ & $\begin{array}{l}-120 \\
-200 \\
-110\end{array}$ & $\begin{array}{l}-80 \\
-180 \\
-60\end{array}$ & $\begin{array}{l}-80 \\
-160 \\
-60\end{array}$ & $\begin{array}{l}-210 \\
-215 \\
-190\end{array}$ & $\begin{array}{l}\text { No localized corrosion } \\
\text { Presence of localized corrosion SCE near the pit } \\
\text { Presence of localized corrosion SCE } 1.5 \mathrm{~m} \text { far from the pit }\end{array}$ \\
\hline
\end{tabular}

potential measured is the average value referred to all the rebar or tendon length.

\subsection{Mechanism by which the MuREs work}

As demonstrated in a previous research [21], once immersed in an electrical field established by the pitting macro-cell current, a linear reference electrode behaves as an interfered metallic wire: some zones of the wire become cathodic, where the current enters the wire (close to the pit), and some others become anodic, where the current leaves the wire. Practically, the metallic wire contributes to the current flow because of its electrical conductivity. The reading has been demonstrated to be the average of the crossed equipotential surfaces [30].

Table 4 summarises for each metallic material the potential values of the three MuREs measured by an external SCE reference electrode, performed to verify the reference electrodes stability after pit initiation. Measurements were carried out at the two holes: over the pit and $1.5 \mathrm{~m}$ far from it, where carbon steel rebar is still in passive conditions, according to potential reported in Fig. 4.

In the absence of a localized corrosion attack, potentials of the metallic wires of the MuREs are stable, independently on the $L / D$ ratio and SCE location: $-220 \mathrm{mV}$ SCE for copper, $-130 \mathrm{mV}$ SCE for nickel and $-150 \mathrm{mV}$ SCE for stainless steel. A strange behavior was observed in the case of oxidized stainless steel wires, due to imperfection in the oxidation process.

In the presence of a localized corrosion attack, the metallic wires of the MuRE far away from the pit are almost stable, while a cathodic polarization was measured on the wire over the pit, confirming the interfered condition of the MuRE during pit propagation.

Potential measurements were performed on LCRE, too. As expected a low polarization effect was detected, due to the length of the wire $(2.5 \mathrm{~m})$ with respect the small anodic site.

\subsection{Estimation of $L / D$ ratio}

Results clearly showed that to have a reliable potential reading a wire of the MuRE should have a proper length, which is dependent on the equipotential surfaces distribution determined by the throwing power of the macrocell induced by the pit, in other words, the extension of the cathodic surface involved in the corrosion process [31-33]. As demonstrated in a previous work [30], the throwing power is the range $0.5 \mathrm{~m}$ to $1.0 \mathrm{~m}$. Being the grout cover $20 \mathrm{~mm}$, the proper $L / D$ ratio is in the range of $25-50$. As a direct consequence, the LCRE here tested, with an $L / D$ ratio of 125
( $=2500 \mathrm{~mm} / 20 \mathrm{~mm}$ ) is clearly not suitable to detect the localized corrosion.

\section{Conclusions}

A novel multi-reference electrode (named MuRE) to monitor chloride-induced corrosion on tendons encased in polymeric duct was designed and tested. It consists of a series of wire-type reference electrodes, each with a proper active length, placed head-to-tail along the tendons. Nickel and stainless were selected as material for the reference electrode since they showed a high potential stability in alkaline condition, not influenced by the water variation into the grout; this is the prerequisite to use a metal as reference electrode.

The tested MuREs were able to promptly detect and locate the occurrence of the chloride-induced corrosion: in fact, once corrosion started, the active portion of the electrode close to the pit showed a potential decrease of about $300 \mathrm{mV}$. Under corrosion condition, the active portion of the reference electrode is interfered by the electrical field promoted by the localized corrosion attack; it was demonstrated that the measured potential is the average potential weighted on the equipotential surfaces crossed by the active portion of the electrode. Accordingly, a reliable potential reading is related to a specific wire length, which is dependent on the electrical field promoted by the throwing power of the current induced by the pit. Based on the tested condition, a single wire is able to detect the occurrence of localized corrosion only if its length is maximum 50 times the cover of the grout. Field tests are mandatory to verify the MuRE reliability in real working condition.

\section{References}

[1] L. Bertolini, B. Elsener, P. Pedeferri, R. Polder, Corrosion of Steel in Concrete, first ed., Wiley-VCH, Weinheim, 2004.

[2] Durability of post-tensioning tendons, FIB Technical Report Bulletin 15, Edited by Luc Taerwe, in: International Federation for Structural Concrete FIB Lausanne, Switzerland, 2001.

[3] Durability specifics for pre-stressed concrete structures: durability of posttensioning tendons, FIB TG 5.4.2, Commission 15, Structural Service Life Aspects; 2004.

[4] EN 206, Concrete. Part 1. Specification, performance, production and conformity. European Committee for Standardization.

[5] EN 1992-1, 1. Eurocode 2: design of concrete structure. Part 1. General rules and rules for building, European Committee for Standardization.

[6] P. Pedeferri, Cathodic protection and cathodic prevention, Constr. Build. Mater. 10 (1996) 391-402.

[7] A. Brenna, F. Bolzoni, S. Beretta, M. Ormellese, Long-term chloride-induced corrosion monitoring of reinforced concrete coated with commercial polymermodified mortar and polymeric coatings, Constr. Build. Mater. 48 (2013) $734-$ 744. 
[8] M. Ormellese, F. Bolzoni, L. Lazzari, A. Brenna, M. Pedeferri, Organic substances as inhibitors for chloride-induced corrosion in reinforced concrete, Mater. Corros. 62 (2011) 170-177.

[9] P. Montes-García, F. Castellanos, J.A. Vásquez-Feijo, Assessing corrosion risk in reinforced concrete using wavelets, Corros. Sci. 52 (2010) 555-561.

[10] J. Ayats, A. Gnagi, B. Elsener, Electrochemical isolation as enhanced protection for post-tensioning tendons in concrete structures, in: Proc. Int. FIB Congress, Prestressed Concrete Engineering Association, vol. 6, Osaka, Japan, Session 8, 2002, pp. 169-176.

[11] M. Della Vedova, B. Elsener, L. Evangelista, Corrosion protection and monitoring of electrically isolated post-tensioning tendons, in: R. Fleisch, $\mathrm{H}$. Irschik, M. Kromme (Eds.), Proc. 3rd European Conference on structural control, 3ESCC, Wien, vol. II, 2004, pp. 47-51.

[12] B. Elsener, Long term monitoring of electrically isolated post-tensioning tendons, FIB J. Struct. Control 6 (2006) 101-106.

[13] S. Yuyama, K. Yokoyama, K. Niitani, M. Ohtsu, T. Uomoto, Detection and evaluation of failures in high-strength tendon of prestressed concrete bridges by acoustic emission, Constr. Build. Mater. 21 (2007) 491-500.

[14] M.K. El-Batanouny, P.H. Ziehl, A. Larosche, J. Mangual, F. Matta, A. Nanni, Acoustic emission monitoring for assessment of prestressed concrete, Constr. Build. Mater. 58 (2014) 46-53.

[15] H.A. Elfergani, R. Pullin, K.M. Holford, Damage assessment of corrosion in prestressed concrete by acoustic emission, Constr. Build. Mater. 40 (2013) 925-933.

[16] B. Elsener, Half-cell potential mapping to assess repair work on RC structures, Constr. Build. Mater. (2001) 133-139.

[17] H.-W. Song, V. Saraswathy, Corrosion monitoring of reinforced concrete structures - a review, Int. J. Electrochem. Sci. 2 (2007) 1-28.

[18] ASTM C876, Standard test method for half-cell potential on reinforcing steel in concrete, American Society for Testing and Materials, West Conshohocken, PA 19428-2959, United States.

[19] B. Elsener, C. Andrade, J. Gulikers, R. Polder, M. Raupach, Recommendation on half-cell potential measurements, Mat. Struct. 36 (2003) 461-471.

[20] T.-H. Ha, S. Muralidharan, J.-H. Bae, Y.-C. Ha, H.-G. Lee, K.-W. Park, D.-K. Kim, Role of sensors in corrosion monitoring and durability assessment in concrete structures: the state of the art, Sens. Mater. 16 (2004) 133-158.
[21] T. Parthiban, R. Ravi, G.T. Parthiban, Potential monitoring system for corrosion of steel in concrete, Adv. Eng. Soft. 37 (6) (2006) 375-381.

[22] S. Muralidharan, T-H. Ha, J-H. Bae, Y-C. Ha, H-G. Lee, D-K. Kim, A promising potential embeddable sensor for corrosion monitoring application in concrete structures, Measurement 40 (2007) 600-606.

[23] S. Muralidharan, V. Saraswathy, A. Madhavamayandi, K. Thangavel, N. Palaniswamy, Evaluation of embeddable potential sensor for corrosion monitoring in concrete structures, Electrochim. Acta 53 (2008) 7248-7254.

[24] S.P. Karthick, S. Muralidharan, V. Saraswathy, K. Thangavel, Long-term relative performance of embedded sensor and surface mounted electrode for corrosion monitoring of steel in concrete structures, Sens. Act. B: Chem. 192 (2014) 303309.

[25] G.S. Duffó, S.B. Farina, C.M. Giordano, Characterization of solid embeddable reference electrodes for corrosion monitoring in reinforced concrete, Electrochim. Acta 54 (2009) 1010-1020.

[26] G.S. Duffó, S.B. Farina, Development of an embeddable sensor to monitor the corrosion process of new and existing reinforced concrete structures, Constr. Build. Mater. 23 (2009) 2746-2751.

[27] S. Muralidharan, T.-H. Ha, J-H. Bae, Y.-C. Ha, H.-G. Lee, K.-W. Park, D.-K. Kima, Electrochemical studies on the performance characteristics of solid metalmetal oxide reference sensor for concrete environments, Sens. Act. B: Chem. 113 (2006) 187-193.

[28] S.-G. Dong, C.-J. Lin, R.-G. Hu, L.-Q. Li, R.-G. Du, Effective monitoring of corrosion in reinforcing steel in concrete constructions by a multifunctional sensor, Electrochim. Acta 56 (2011) 1881-1888.

[29] S. Feliu, J.A. González, J.M. Miranda, V. Feliu, Possibilities and problems of in situ techniques for measuring steel corrosion rates in large reinforced concrete structures, Corros. Sci. 47 (2005) 217-222.

[30] M. Ormellese, A. Brenna, L. Lazzari, Use of a linear continuous reference electrode to monitor the chloride-induced corrosion of steel in prestressed concrete, Mater. Corros. 66 (2015) 35-44.

[31] L. Bertolini, P. Pedeferri, T. Pastore, B. Bazzoni, B.L. Lazzari, Corr., 52, 552, 1996.

[32] T.J. Barlo, R.R. Fessler, presented at Int. Conf. Corrosion/83, NACE International, Houston, TX, paper 292, 1983.

[33] L. Lazzari, P. Pedeferri, Cathodic Protection, first ed., Polipress, Milan, 2006. 